\title{
Evaluation and Comparative Study of Cell Balancing Methods for Lithium-Ion Batteries Used in Electric Vehicles
}

\author{
Duraisamy Thiruvonasundari * and Kaliyaperumal Deepa
}

Department of Electrical and Electronics Engineering, Amrita School of Engineering, Bengaluru, Amrita Vishwa Vidyapeetham, India

\begin{abstract}
Vehicle manufacturers positioned electric vehicles (EVs) and hybrid electric vehicles (HEVs) as reliable, safe and environmental friendly alternative to traditional fuel based vehicles. Charging EVs using renewable energy resources reduce greenhouse emissions. The Lithium-ion (Li-ion) batteries used in EVs are susceptible to failure due to voltage imbalance when connected to form a pack. Hence, it requires a proper balancing system categorised into passive and active systems based on the working principle. It is the prerogative of a battery management system (BMS) designer to choose an appropriate system depending on the application. This study compares and evaluates passive balancing system against widely used inductor based active balancing system in order to select an appropriate balancing scheme addressing battery efficiency and balancing speed for E-vehicle segment (E-bike, E-car and E-truck). The balancing systems are implemented using "top-balancing" algorithm which balance the cells voltages near the end of charge for better accuracy and effective balancing. The most important characteristics of the balancing systems such as degree of imbalance, power loss and temperature variation are determined by their influence on battery performance and cost. To enhance the battery life, MatlabSimscape simulation-based analysis is performed in order to fine tune the cell balancing system for the optimal usage of the battery pack. For the simulation requirements, the battery model parameters are obtained using least-square fitting algorithm on the data obtained through electro chemical impedance spectroscopy (EIS) test. The achieved balancing time of the passive and active cell balancer for fourteen cells were 48 and $20 \mathrm{~min}$ for the voltage deviation of $30 \mathrm{mV}$. Also, the recorded balancing time was 215 and 42 min for the voltage deviation of $200 \mathrm{mV}$.
\end{abstract}

Keywords: Electric vehicle, Lithium-ion battery, Energy efficiency, Temperature behaviour and Cost analysis.

Article History: Received: 20 th November 2020; Revised: 26 th January 2021; Accepted:10th Feb 2021; Available online: $18^{\text {th }}$ Feb 2021

How to Cite This Article: Thiruvonasundari,D. and Deepa, K. (2021) Evaluation and Comparative Study of Cell Balancing Methods for LithiumIon Batteries Used in Electric Vehicles. Int. Journal of Renewable Energy Development, 10(3), 471-479 https://doi.org/10.14710/ijred.2021.34484

\section{Introduction}

A Li-ion battery pack which is used in EVs consists of several cells assembled in series and in parallel to deliver the required voltage and capacity. Any discrepancy in the capacity and voltage of the connected cells affect the efficiency of the whole battery pack (Omariba et al., 2018). This may happen due to various environmental factors or manufacturing differences which introduce variations in the EV cell specifications resulting in a performance degradation (Jonathan et al., 2020).

In order to recover the maximum battery pack energy, a balancing scheme is incorporated using BMS for EVs. The balancing systems which remove excess energy from the over charged cells are categorised into passive and active (Ouyang et al., 2020). Passive system uses a dissipative resistor to bleed excess charge from the highly charged cell and active system uses an energy storing element to transfer excess charge to a low charged cell, thus facilitating support between a strong and a weak cell (Campbell et al., 2019). The cell balancing system used in EVs typically involves three modes of operation as shown in Fig. 1 (Omariba et al., 2019).
Balancing is employed to maximise the energy delivered to or from the cell during the process of charging or discharging. The idle balancing mode operates when the cell is neither charged nor discharged. The balancing algorithms used in the balancer is either voltage (Hoque et al., 2015) or charge based (Ma et al., 2018) which are applicable to both active and passive balancing schemes.

Passive balancing scheme, shown in Fig. 2 is extensively used in EV applications due to its low cost and easy implementation (Koseoglou et al., 2020). Problem consists of excess heat dissipation due to the balancing resistor, long balancing time and low efficiency. Balancing current must be kept low to reduce power loss and manage thermal issues (Stuart et al., 2009). Recently Xu et al. (2019) used MOSFET (metal-oxide-semiconductor fieldeffect transistor) switch as a variable resistor instead of the balancing resistor to handle the power dissipation optimally. In the passive scheme to tackle huge power loss, a proper thermal management system needs to be implemented in order to control any inadvertent rise in temperature which leads to pack degradation. Currently, active topologies are replacing traditional passive systems

\footnotetext{
* Corresponding author: sundarisamy@gmail.com
} 
to handle power loss and heat dissipation issues (Jonathan et al., 2020).

Active balancing schemes are classified into capacitor, inductor and transformer based (Hemavathi, 2020). Capacitor based scheme offers low implementation cost, but the balancing speed is low (Lee et al., 2016). Transformer based scheme has a high balancing speed and it requires high cost due to the presence of a transformer (Gallardo-Lozano et al., 2014). Inductor scheme gives a better performance with a trade-off between balancing speed and implementation cost (Xie et al., 2011). A next-to-next inductor balancing topology (Phung et al., 2014) consists of (N-1) inductors which transfers energy between adjacent cells, extending the battery discharge time, however the presence of a higher number of components makes it difficult to implement. Single switch per cell with unidirectional balancing (Kim et al., 2014) reduces the number of switches but has drawbacks in the form of voltage stress on the centre-cell switch. Dong et al. (2015) presented a solution to overcome the slow balancing time of the charge equalizer by fixing independent equalizers in different layers. To enhance equalization current and efficiency, any-cell-to-any-cell bidirectional inductor-based topology was introduced by Zhou et al. (2016). However, the presence of a high number of switches lead to higher costs and size.

The topology discussed by Kumar et al. (2017) offers the fastest balancing time using a single switch inductor. The inductor-based system proposed by Moghaddam and Van Den Bossche (2018) exhibits excellent characteristics with reduced complexity and fewer components when compared to traditional inductor based balancing system (Cassani and Williamson, 2009). By using a coupled inductor (Moghaddam and Van Den Bossche, 2019) as shown in Fig.3a instead of a traditional one (Xie et al., 2011) as shown in Fig.3b, can reduce the number of components and the cost further. The traditional scheme uses (N-1) inductors and $2(\mathrm{~N}-1)$ switches for $\mathrm{N}$ number of cells, coupled scheme needs $\mathrm{N} / 2$ inductors and $\mathrm{N}$ switches for $\mathrm{N}$ number of cells.

In a non-hybrid electric car, such as BMW i3, 96 cells are installed in series which has a total battery voltage of around $360 \mathrm{~V}$. In electrified trucks and passenger electric vehicles, the maximum DC link voltage may reach up to $870 \mathrm{~V}$, and often called as $800 \mathrm{~V}$ system (Jung, 2017). These types of high-power electric vehicles need to employ active balancing system for the effective use of power.

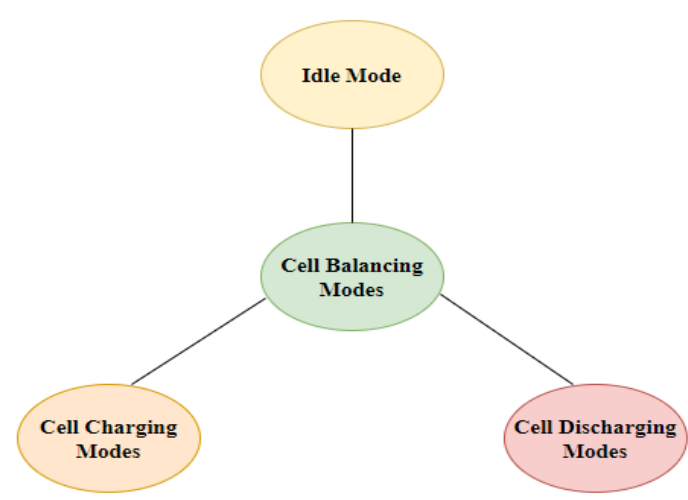

Fig. 1 Cell Equalization modes

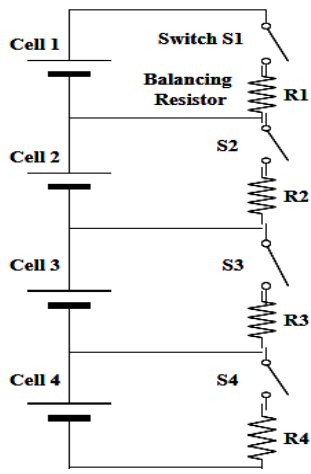

Fig. 2 Passive balancing

(a)

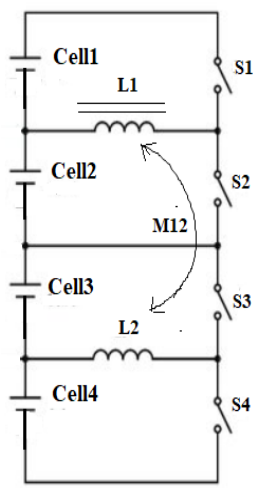

Fig. 3(a) Coupled inductor and (b) Traditional inductor

Table 1

Comparison of balancing schemes from the literatures (Daowd et al., 2011; Kim et al., 2014; Casper et al., 2018; Omariba et al., 2019)

\begin{tabular}{|c|c|c|c|c|}
\hline $\begin{array}{l}\text { Balancing } \\
\text { attributes }\end{array}$ & $\begin{array}{l}\text { Passive } \\
\text { balancing }\end{array}$ & $\begin{array}{l}\text { Capacitor based } \\
\text { balancing }\end{array}$ & Inductor based balancing & $\begin{array}{l}\text { Transformer based } \\
\text { balancing }\end{array}$ \\
\hline Preferred Mode & Charging & Charging, discharging & Charging & Charging \\
\hline Balancing speed & Slow & Slow & Fast & Faster \\
\hline Size & Small & Medium & Medium & Bulky \\
\hline Cost & Economical & Expensive & Moderate & Very expensive \\
\hline Modularization & Simple & Moderate & Moderate & Difficult to Modularize \\
\hline Efficiency & $>90 \%$ & $88 \%$ to $95 \%$ & $>95 \%$ & $80 \%$ to $95 \%$ \\
\hline Control complexity & Simple & Complex & Moderate & Complex \\
\hline Implementation & Simple & Complex & Complex & Complex \\
\hline Merits & $\begin{array}{l}\text { Easy to realize } \\
\text { Low cost }\end{array}$ & $\begin{array}{l}\text { Simple control, no need for } \\
\text { closed-loop control }\end{array}$ & $\begin{array}{l}\text { Faster balancing, good } \\
\text { efficiency, relatively cheap }\end{array}$ & $\begin{array}{l}\text { Faster balancing, low switch } \\
\text { voltage/ current stress }\end{array}$ \\
\hline Demerits & $\begin{array}{l}\text { Energy is } \\
\text { dissipated as heat, } \\
\text { slow balancing }\end{array}$ & $\begin{array}{l}\text { Low balancing speed, a } \\
\text { greater number of switches }\end{array}$ & $\begin{array}{l}\text { Filtering capacitors are } \\
\text { needed for high switching } \\
\text { frequency }\end{array}$ & $\begin{array}{l}\text { High cost, size, complex } \\
\text { control }\end{array}$ \\
\hline
\end{tabular}




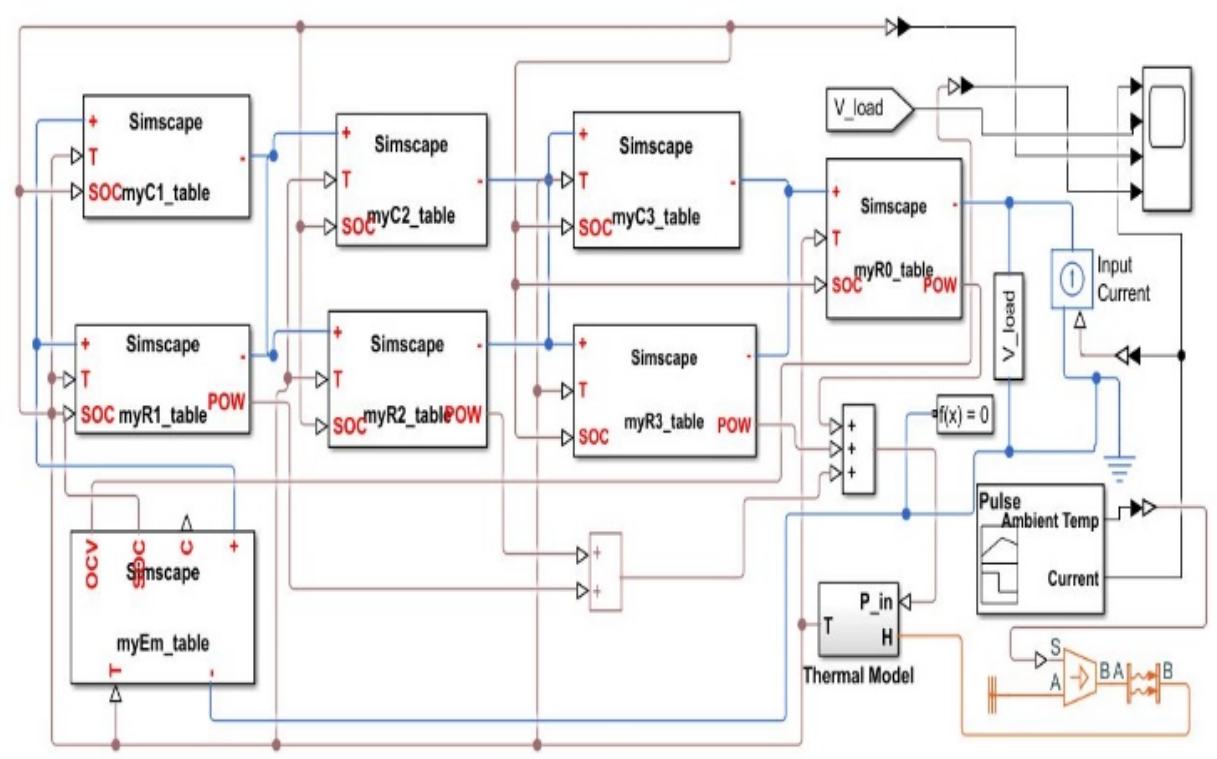

Fig. 4 Battery 3RC ECM model in Matlab-Simscape

The necessity of a balancing system is to improve the power and energy stipulations, energy efficiency and life cycle extension of the battery system (Hua et al., 2020). This research work analyses the passive and inductor based active cell balancing characteristics which are explored by Thiruvonasundari and Deepa (2020) with respect to power level, cell balancing mode, thermal characteristics and implementation cost to select a suitable balancing method for battery powered EVs. Table 1 compares the balancing system from the available literature.

This paper is organized as follows: Section 2 discusses the balancing principle and design methodology. Section 3 describes simulation techniques and captures the outcomes of active and passive balancing schemes. In Section 4, simulation results are compared against balancing parameters and the balancing method suitable for different E-vehicle segment, followed by the conclusion in Section 5.

\section{Methodology}

\subsection{Balancing Principle}

Passive and active cell balancing algorithms rely on voltage balancing strategies. The algorithms check whether the voltage difference between any two cells is more than the threshold value, the passive system dissipates the excess energy through the balancing resistor whereas in an active system an inductor transfers excess energy to low energy cells. The balancing thresholds could be further fine-tuned by increasing the accuracy of the sampling circuit and based on the system requirements. Table 2 summarizes the cell specifications for the balancing system.

To simulate the balancing system, a proper battery cell model is required. The most widely used equivalent circuit model (ECM) is chosen for the state estimation (Zheng et al., 2018). Li-ion nickel manganese cobalt (NMC) cells have been tested and their parameters were estimated as discussed by Thiruvonasundari and Deepa (2020). A complete battery model is drafted by the 3RC equivalent circuit modelling approach. The cell balancing is performed by using a model-based simulation in a Matlab-Simscape (R2019a) environment as represented in Fig. 4. This model describes open circuit voltage (OCV), state of charge (SOC) and state of health $(\mathrm{SOH})$ variable parameters as a function of temperature and SOC. The 3RC elements are accurately capture the battery system dynamics and the thermal block is used to model the battery temperature. Figures 5 and 6 show the OCV and internal resistance $\left(\mathrm{R}_{0}\right)$ of the battery with respect to SOC.

The internal resistance of the model reflects the battery SOH. The various drive cycles such as urban dynamometer driving schedule (UDDS), new European drive cycle (NEDC) are studied to perform the cell balancing. In this work, the cell balancing algorithm is set to activate the balancing when all the cell voltages are above $3.9 \mathrm{~V}$ (top-balancing) and $\Delta \mathrm{V}>30 \mathrm{mV}$. The simulation was performed by varying the cell initial voltages of values from $3.57 \mathrm{~V}$ to $4.16 \mathrm{~V}$ with a minimum to maximum voltage deviation of the cells between $30 \mathrm{mV}$ to $230 \mathrm{mV}$. The balancing architecture, working principle, control flow algorithm, modes of operation and simulation outcome of inductor cell balancing schemes are explained in Thiruvonasundari and Deepa (2020).

Table 2

Li-ion battery pack specifications for 18650-NMC cells

\begin{tabular}{ll} 
Cell Specifications & Value \\
\hline Number of cells & 14 \\
Pack voltage & $48 \mathrm{~V}$ \\
Capacity & $3.35 \mathrm{Ah}$ \\
Maximum charge voltage & $4.2 \mathrm{~V}$ \\
Minimum discharge voltage & $2.5 \mathrm{~V}$ \\
Balancing voltage & $3.9 \mathrm{~V}$ \\
\hline
\end{tabular}




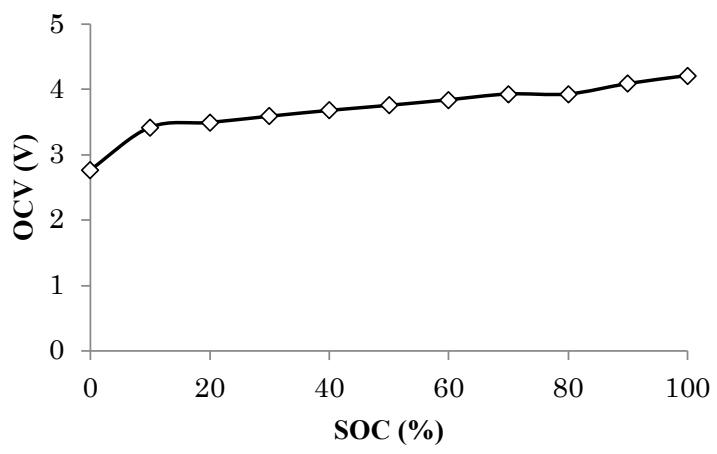

Fig. 5 Battery model SOC Vs OCV

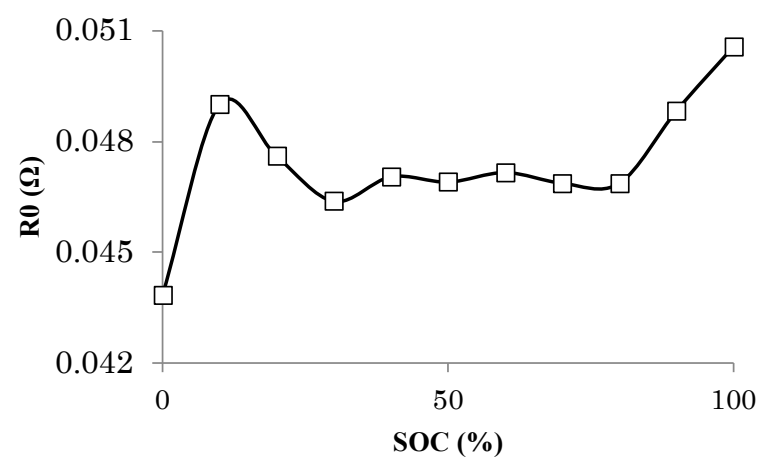

Fig. 6 Battery model SOC Vs $\mathrm{R}_{0}$

\subsection{Cell Balancing Design}

Energy efficiency is a major factor to be considered while designing electrical energy storage applications (Chen et al., 2020). Achieving higher energy efficiency during the cell balancing process involves optimal dimensioning of the cell balancing system, thus saving precious energy instead of wasting it in the form of heat. In both passive and active balancing system implementations, several resistors, inductors and MOSFET switch variants may be used in the balancing circuit design. Each minor configuration for a certain balancing current has the potential to alter energy dissipation and volume of the balancing architecture.

The balancing current is not only responsible for energy dissipation, but also determines the speed of the charge transfer process. The passive system uses relatively low balancing current, to drain the excess charge from overcharged cells.

$I_{B}=\frac{V_{C}}{R_{B}}$

Where,

- $V_{C}$ is the cell voltage

- $R_{B}$ is the balancing resistor

The cell balancing current of $\mathrm{C} / 100$ is sufficient for the system (Amin et al., 2017), a balancing current of $100 \mathrm{~mA}$ finds the balancing resistor of $37 \Omega$. Though higher balancing current reduces the balancing time but it increases the energy loss.
Table 3

Properties of MOSFET \& Inductor

\begin{tabular}{llll}
\hline MOSFET & Symbol & Inductor & Symbol \\
\hline Max. Current & $I_{\max }$ & Max. Current & $I_{\max }$ \\
Switch resistance & $R_{D S}$ & Inductance & $\mathrm{L}$ \\
O/P Capacitance & $C_{\text {oss }}$ & DC Resistance & $R_{\text {ind }}$ \\
Delay time & $t_{\text {on }}, t_{\text {off }}$ & Volume & $v_{\text {ind }}$ \\
Volume & $v_{m}$ & & \\
\hline
\end{tabular}

(a)

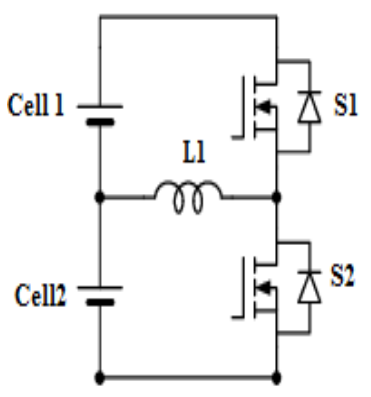

(b)

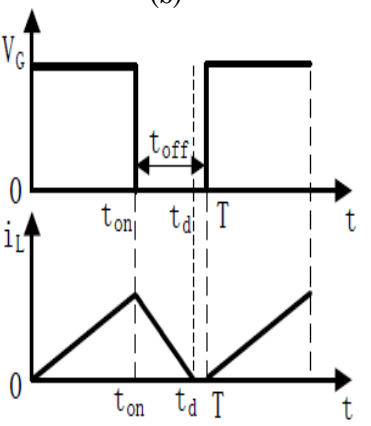

Fig. 7(a) Balancing operation and (b) DCM mode

Energy loss $=$ Power loss $\times$ Balancing time

$E_{\text {loss }}=\frac{V^{2}}{R_{B}} \times t_{B} \quad$ or $\quad I_{B}^{2} R_{B} \times t_{B}$

The reduction in balancing time mandates, higher current requirement on the MOSFET and high wattage rating on the bleeding resistors. The properties of MOSFET and inductors which influence the balancing parameters of the balancing architecture are listed in Table 3 (Narayanaswamy et al., 2014).

The selection of balancing inductor in a circuit is based on the rated current of the battery. In inductor balancing, the energy stored in the inductor at the first stage (when the switch is closed) is fully transferred to the low voltage cell in the second stage (when the switch is opened and diode works), the duty cycle $\mathrm{D}$ should be $<0.5$ cycle. So, the balancing inductor works in discontinuous current mode (DCM). The DCM mode of DC-DC converter operation is shown in Fig.7a and b (Wang et al., 2017). When switch $\mathrm{S} 1$ is turned on, the cell1 voltage charges the inductor L1 (Wang et al., 2017).

$V_{\text {Lon }}=i_{\text {Lon }} R_{0 n}+L 1 \frac{d i_{\text {Lon }}}{d t}+V_{m}, 0<\mathrm{t} \leq t_{0 n}$

Where,

- $V_{L o n}$ is the voltage across L1

- $i_{L o n}$ is the current through the inductor

- $R_{0 n}$ is the total resistance in the current path

- $V_{m}$ is the voltage drop across the MOSFET

When switch $\mathrm{S} 1$ is turned OFF, the energy stored in the inductor is transferred to cell 2 and voltage across the inductor is denoted by $V_{\text {Loff }}$.

$V_{L o f f}=i_{\text {Loff }} R_{0 f f}+L 1 \frac{d i_{L o f f}}{d t}-V_{d}, t_{0 n}<t \leq t_{d}$

Where, 
- $V_{d}$ is the forward voltage drop across the MOSFET diode,

- $t_{d}$ is the time when the inductor current drops to zero.

The on and off time of the switch is calculated as below

$t_{o n}=\frac{L 1 . i_{p}}{\left(V_{L o n}-V_{m}\right)}$

$t_{o f f}=\frac{L 1 \cdot i_{p}}{\left(V_{L o f f}-V_{D}\right)}$

The peak value of the inductor current is calculated from Eqn. (6)

$i_{p}=\frac{\left(V_{L o n}-V_{m}\right) t_{o n}}{L 1}$

By ignoring the drop across the switch,

$i_{p}=\frac{\left(V_{L o n} t_{o n}\right)}{L 1}=\frac{\left(V_{L o n}\right) D . T}{L 1}$

The average value of inductor and battery currents are:

$i_{\text {avr }}=\frac{\left(V_{L o n}\right) D}{2 L 1 f}$

$i_{\text {Bavr }}=\frac{\left(V_{\text {Lon }}\right) \cdot D^{2}}{2 L 1 f}$

The average value of balancing current is inversely proportional to the inductance and switching frequency. Due to the inverse relationship between balancing time and current, the balancing time is dependent on $\mathrm{L}$ and $\mathrm{f}$. The size of the inductor can be reduced further by increasing the switching frequency.

\section{Results}

In this simulation, it was found that the passive balancer takes very long time, owing to higher voltage difference between the cells is as shown in Fig.8 and 9. This limitation of passive cell balancing is overcome by using active cell balancing, as given in Fig.10 and 11. The power loss across the balancing system could be a major cause for the temperature rise near the battery pack, decreasing the battery life by stimulating the aging mechanisms. Comparison of temperature characteristics is done by evaluating the maximum temperature $\left(\mathrm{T}_{\max }\right)$ and temperature distribution $(\Delta \mathrm{T})$ among the cells. The active system reaches lower maximum temperature $\left(24^{\circ} \mathrm{C}\right)$ than passive system $\left(27^{\circ} \mathrm{C}\right)$ and $\Delta \mathrm{T}$ does not exceed $4^{\circ} \mathrm{C}$ at the time of charging as represented in Fig. 12 and 13 where $\Delta \mathrm{V}>30 \mathrm{mV}$.

Table 4

Passive system energy efficiency and cost calculation

\begin{tabular}{|c|c|c|c|c|c|c|}
\hline $\begin{array}{l}\Delta \mathrm{V} \\
(\mathrm{mV})\end{array}$ & $\begin{array}{l}\text { Cells } \\
\text { (\#) }\end{array}$ & $\begin{array}{l}P_{\text {loss }} \\
\text { (W) }\end{array}$ & $\begin{array}{l}\text { BT } \\
(\mathrm{min})\end{array}$ & $\begin{array}{l}E_{\text {loss }} \\
\text { (Wh) }\end{array}$ & $\begin{array}{l}y \\
(\%)\end{array}$ & $\begin{array}{l}\text { Cost } \\
(\$)\end{array}$ \\
\hline \multirow{2}{*}{30} & 1 & 0.35 & 48 & 0.28 & 99.83 & 0.04 \\
\hline & 13 & 4.55 & 48 & 3.64 & 97.84 & 0.49 \\
\hline \multirow{2}{*}{200} & 1 & 0.35 & 215 & 1.25 & 99.26 & 0.17 \\
\hline & 13 & 4.55 & 215 & 16.30 & 90.34 & 2.17 \\
\hline
\end{tabular}

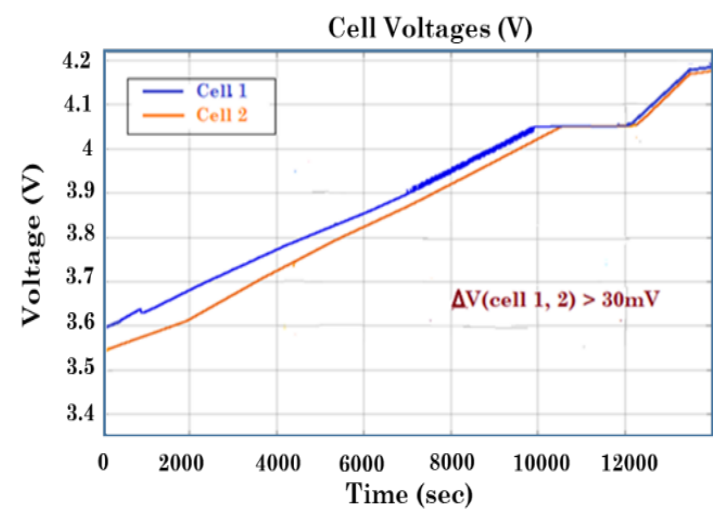

Fig. 8 Passive balancing (Charging)

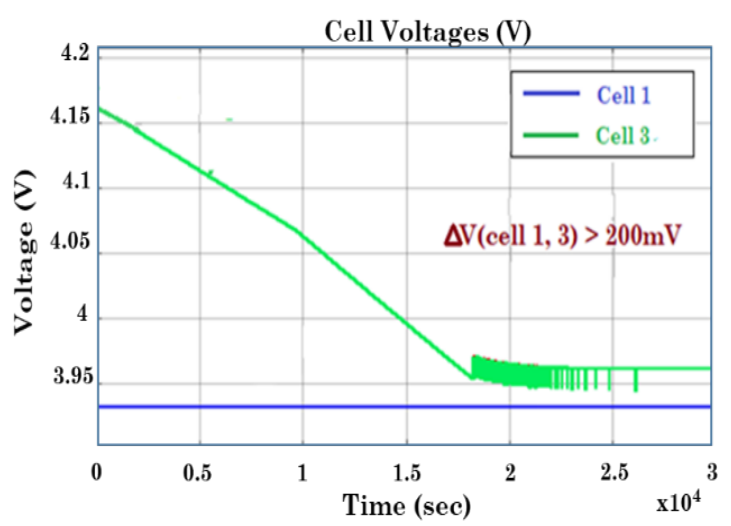

Fig. 9 Passive balancing (Idle)

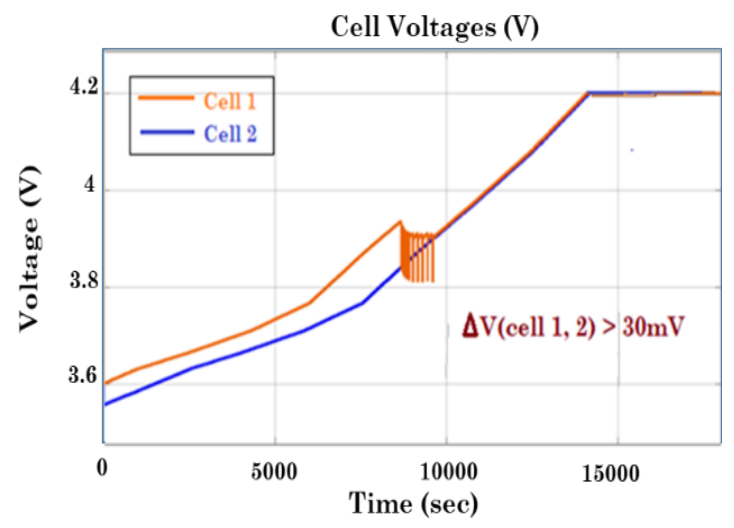

Fig. 10 Active balancing (Charging)

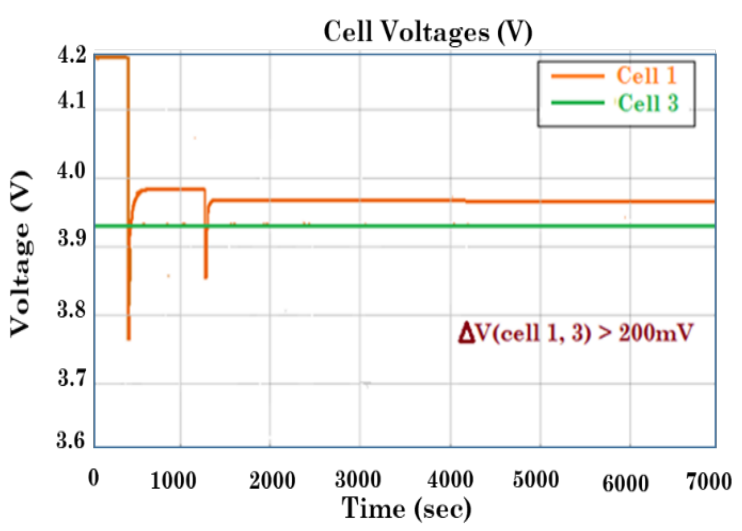

Fig. 11 Active balancing (Idle) 
Citation: Thiruvonasundari,D. and Deepa, K. (2021) Evaluation and Comparative Study of Cell Balancing Methods for Lithium-lon Batteries Used in Electric Vehicles. Int. Journal of Renewable Energy Development, 10(3), 471-479, doi:10.14710/ijred.2021.34484

$\mathrm{P}$ a g e $\mid 476$

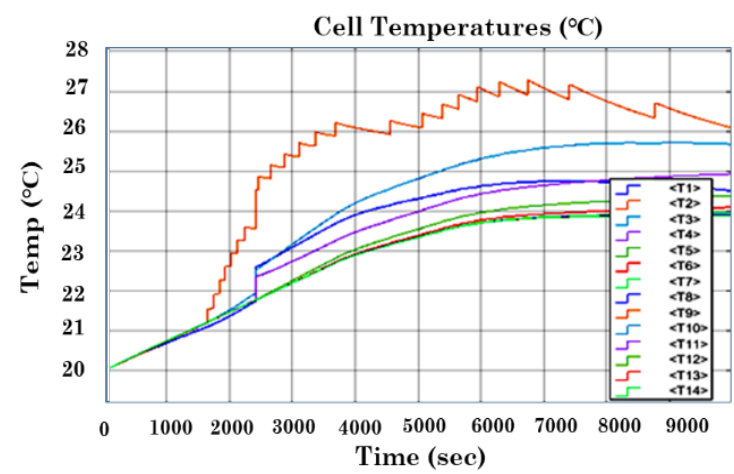

Fig. 12 Temperature rise (Passive)

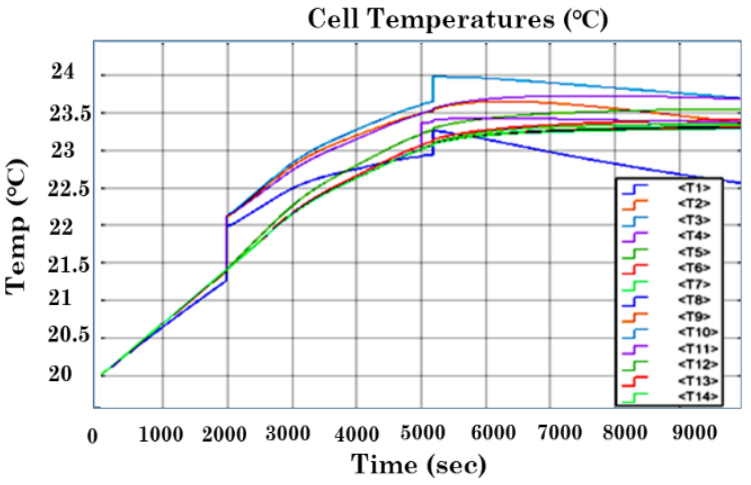

Fig. 13 Temperature rise (Active)

Table 5

Active system energy efficiency and cost calculation

\begin{tabular}{|c|c|c|c|c|c|c|}
\hline $\begin{array}{c}\Delta V \\
(\mathrm{mV})\end{array}$ & $\begin{array}{c}\text { Cells } \\
(\#)\end{array}$ & $\begin{array}{l}\text { Ploss } \\
\text { (W) }\end{array}$ & $\begin{array}{c}\text { BT } \\
\text { (min) }\end{array}$ & $\begin{array}{l}E_{\text {loss }} \\
\text { (Wh) }\end{array}$ & $\begin{array}{c}y \\
(\%)\end{array}$ & $\begin{array}{c}\text { Cost } \\
\text { (\$) }\end{array}$ \\
\hline \multirow{2}{*}{30} & 1 & 0.07 & 15 & 0.02 & 99.9 & 0.003 \\
\hline & 13 & 1.05 & 20 & 0.35 & 99.7 & 0.047 \\
\hline \multirow{2}{*}{200} & 1 & 0.4 & 35 & 0.23 & 99.86 & 0.031 \\
\hline & 13 & 1.16 & 42 & 0.81 & 99.51 & 0.108 \\
\hline
\end{tabular}

\subsection{Calculation of key parameters from simulation}

The simulation result provides many key parameters including balancing time, power loss, energy loss, energy efficiency and the cost of the lost energy. Tables 4 and 5 show the passive and active simulation outcome of a typical $48 \mathrm{~V}$ E-bike system. Using passive balancing, it is observed that a considerable energy loss occurs only when the cell imbalance is high. In contrast to passive system, the energy loss is observed to be low in the active topology, irrespective of the number of cells and voltage deviation $(\Delta \mathrm{V})$.

\section{Discussion}

\subsection{E-vehicle use cases}

In low power E-bikes, the number of series connected cells going out of balance are considerably low. Among fourteen cells, for a single cell balancing, passive balancer took 48 min to bring down the difference to $30 \mathrm{mV}$ (shown in Fig.8).
Table 6

Comparison of cell balancing system characteristics

\begin{tabular}{lllllll}
\hline Parameters & \multicolumn{2}{c}{ E-Bike } & \multicolumn{2}{c}{ E-Car } & \multicolumn{2}{c}{ E- Truck } \\
& PB & AB & PB & AB & PB & AB \\
\hline Cells in series & 14 & 14 & 96 & 96 & 250 & 250 \\
$\Delta V(m V)$ & 30 & 30 & 30 & 30 & 30 & 30 \\
Ploss $_{\text {(W) }}$ & 4.55 & 1.05 & 38 & 9.5 & 99.6 & 24.9 \\
BT(Min) & 48 & 20 & 48 & 20 & 48 & 20 \\
Eloss $_{\text {(Wh) }}$ & 3.64 & 0.35 & 30.4 & 3.2 & 80 & 8.3 \\
y (\%) & 97.8 & 99.7 & 97 & 99 & 96.7 & 98.5 \\
Eloss cost (\$) & 0.49 & 0.05 & 4.05 & 0.4 & 10.7 & 1.11 \\
\hline
\end{tabular}

$\mathrm{PB}$ - Passive Balancing, AB - Active Balancing

The power dissipation of $0.35 \mathrm{~W}$ is observed across the balancing resistor which is insignificant (shown in Table 4). Since the heat dissipation is minimum in passive balancing, active balancing is not a feasible option due to high cost and circuit complexity. Hence, the passive balancing is suitable for low power E-bikes. If cells are aged (cycled many times), the voltage deviation is maximum and the pack contains a greater number of imbalanced cells and the passive balancer took $215 \mathrm{~min}$ to balance with a power loss of $4.55 \mathrm{~W}$ is observed. This loss is significant (as shown in Table 4), hence the passive balancing is not a feasible option for aged out cells and high-power battery pack (possibility of more imbalanced cells). The active balancer took 15 to $42 \mathrm{~min}$ for $\Delta \mathrm{V}$ is from $30 \mathrm{mV}$ to $200 \mathrm{mV}$ is shown in Table 5. Table 6 illustrates a comparative study of the cell balancing system characteristics of EV variants. It is observed that cost saving from the energy loss is not significant even with passive balancing though power loss is reduced drastically with active balancing. Due to the excess energy loss the passive cell balancing system produce hot spots within the pack which limits the battery state of health and the remaining useful life of the battery (Lipu et al., 2018).

In the recent years, life cycle assessment studies are conducted on next generation Li-ion batteries for EVs, including Si-Nanotube based, molybdenum disulfide Liion battery to do environmental impact analysis (Deng et al., 2019).

\subsection{Balancing under charging, discharging and idle state}

Passive cell balancing is applied during charging when the voltage of a cell has reached the maximum voltage threshold (Koseoglou et al., 2020). It is suitable for charging as some of the battery energy will be dissipated. The balancing process is completed ( $48 \mathrm{~min}$ ) within the charging period (5 to $6 \mathrm{hr}$ ) is shown in Table 4. For maximum voltage deviation $(>200 \mathrm{mV})$, it took more time to balance (215 min). Hence, based on the degree of imbalance, the balancing algorithm needs to decide when to initiate the balancing process whether in the beginning or end of charging in order to balance the cells within the charging time. The balancing current is restricted to the maximum heat dissipation of the balancing resistor; thus, the balancing is slow and makes an issue for fast-DC charging application (Wager et al., 2016). As active 
balancing redistributes the excess charge and ensures that the cells are balanced even when the EVs are at the beginning of charging, driving or parked. The active balancer took almost same time for minimum to maximum voltage deviations as shown in Table 5. It can balance cell voltages rapidly, with suitable balancing current results at a higher charging efficiency (Chol-Ho et al., 2013). Table 7 illustrates C-rate and time while discharging and charging batteries of $1 \mathrm{Ah}$ (Collin et al., 2019).

In most cases, the safely accepted C-rate of the EV batteries is still restricted to 1-1.5 C. Various charging schemes (Tomaszewska et al., 2019) have been proposed for fast charging of Li-ion batteries as illustrated in Fig. 14. CC-CV plot indicates the constant current charging behavior till the battery voltage reaches up to a cut-off value and followed by a constant voltage until the current falls to prescribed minimum value.

In CP-CV constant power in the beginning of charging followed by a CV. Multistage CC-CV (MCC-CV) plot shows three CC stages followed by a CV. Pulse charger feed the charge current in pulses and charging current rate is varied by varying the width of the pulses is shown in pulse charging plot. High charge current at the beginning of charging followed by a moderate current with CC-CV profile in the boost charging scheme is shown in the Boost Charging plot. VCP plot shows a greater number of variable current profiles for fast charging.

Table 7

C-rate vs Charging time

\begin{tabular}{cc} 
C-rate(C) & Time (hr) \\
\hline 5 & 0.2 \\
2 & 0.5 \\
1 & 1 \\
0.5 & 2 \\
0.2 & 5 \\
0.1 & 10 \\
0.05 & 20 \\
\hline
\end{tabular}

Source: batteryuniversity.com
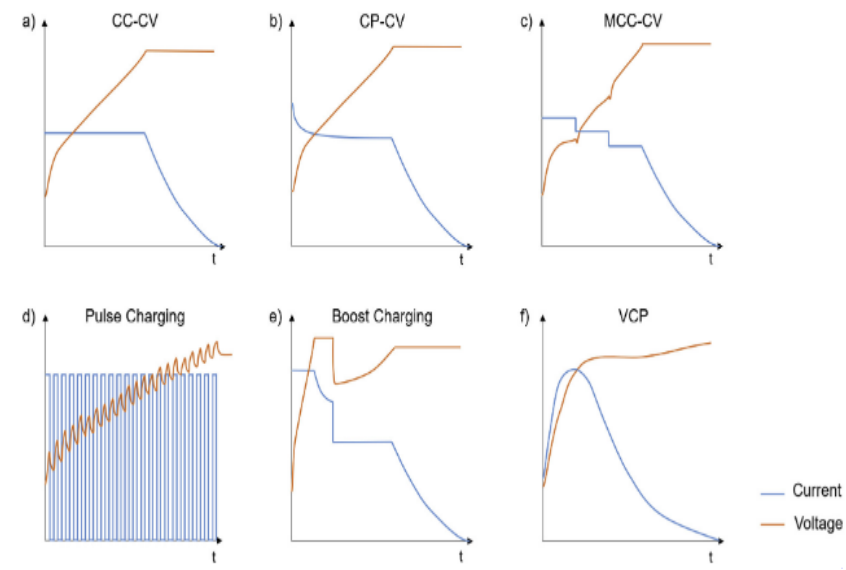

Fig. 14 Charging methods proposed for fast charging. a) Constant Current - Constant Voltage b) Constant Power - Constant Voltage c) Multistage CC-CV d) Pulse Charging e) Boost Charging with a CC-CV-CC-CV f) Variable Current Profile
Table 8

Balancing system elements and cost (14 cells, 48V battery system)

\begin{tabular}{|c|c|c|c|c|}
\hline \multicolumn{4}{|c|}{ Key element cost comparison } & \multirow[b]{2}{*}{$\begin{array}{l}\text { Existing } \\
\mathrm{AB}(\$)^{*}\end{array}$} \\
\hline Key parts & PB (\$) & AB (\$) & $\begin{array}{l}\text { Existing } \\
\text { PB (\$)* }\end{array}$ & \\
\hline $\begin{array}{l}\text { BMS IC } \\
\text { Complex }\end{array}$ & 13.3 & 16.00 & 57.4 & 42.36 \\
\hline $\begin{array}{l}\text { Resistor/ } \\
\text { Inductor }\end{array}$ & 1.96 & 19.95 & 3.92 & 31.92 \\
\hline
\end{tabular}

* Existing scheme cost is for $4 \mathrm{~S} 1 \mathrm{P}$, so derived it for $48 \mathrm{~V}$

\subsection{Energy concerns}

The charging efficiency of the passive system is low compared to active system, due to power loss across the balancing resistor and it is further reducing for high power EVs (shown in Table 6). The energy loss incurred in passive system is calculated by measuring the cell voltage, balancing resistor and the balancing time as represented in Eqn. (2 and 3), whereas the active system produces heat due to balancing converter power losses. Sometimes the active system in standby mode, the power wastage leads to greater loss than the passive balancing (Davide Andrea, 2010). Tables 4 and 5 show increase in energy efficiency by $1.86 \%$ for the maximum number of imbalanced cells and by $9.17 \%$ for the cells with high voltage deviation. This is significantly higher than the results (1\% and 6\%) discussed by Iosu Aizpuru et al. (2017). So, active balancing is recommended for the application which needs a medium or large battery pack that should be extremely energy efficient. The power handled during balancing is on the range of 0.1 to $10 \mathrm{~W}$ then the passive balancing could be a better option (shown in Table 6).

\subsection{Temperature behavior}

In order to improve the power capacity $\mathrm{Ni}$ content in NMC cells are increased in different variants, (from NMC111 to NMC811) but high reactivity of the cathode material with the electrolyte introduces safety issues due to increase in temperature (Ma et al., 2016).

During thermal run-away test, at high temperatures the cylindrical Li-ion cells with NMC cathode showed a poor temperature tolerance (Lei et al., 2017). Packing a set of similar performance cells while manufacturing modules have shown an equalized temperature distribution and lowered rise in temperature (Li et al., 2019). The temperature performance of the battery pack is highly dependent on the balancing system which controls parameters such as temperature deviation $(\Delta \mathrm{T})$ between the cells and maximum temperature of the battery pack $\left(\mathrm{T}_{\max }\right)$ as per the experiments conducted (shown in Fig.12 and 13). The power loss across each cell is responsible for the temperature rise in the battery pack (Abronzini et al., 2019). The balancing system equalizes the cell voltages so that the $\Delta \mathrm{T}$ between the cells are reduced and $\mathrm{T}_{\max }$ is found to be low in the case of active (shown in Fig.13).

\subsection{Total cost of the balancing system}

Passive systems architecture represented in Fig. 2 require a power MOSFET switch $S_{n}$ in combination with a 
balancing resistor $R_{B}$ to dissipate the excess energy of the cells. Active systems have complex architecture as represented in Fig. 3a i.e., they need a greater number of active switches and inductors. The total system cost of passive and active systems could be reduced by using a specific battery management system ICs. Table 8 shows that this scheme is more cost effective than the scheme discussed by Dong et al. (2015).

\section{Conclusions and Future Research Orientations}

For longer life-span and reliable performance of EV battery packs, cell balancing algorithm is a key contributor. Passive balancing finds application in low power systems (E-bike, E-rickshaw, etc.) with cells which are closely matched and charged through conventional charging method. Battery pack for high power applications (E-car, E-truck, etc.) contains greater number of series connected cells which may contribute significant imbalance and hence needs a high current active balancing topology. While balancing, the temperature deviation $(\Delta \mathrm{T})$ among the cells is less than $1^{\circ} \mathrm{C}$ in the active system and around $3^{\circ} \mathrm{C}$ in the passive system. By using active balancing, the efficiency of the battery system is enhanced; $2 \%$ for cells having low $\Delta \mathrm{V}$ and about $9 \%$ for cells having high $\Delta \mathrm{V}$. Passive system is simple and the implementation cost is low, but it involves high investment to have a thermal management system. Though the active system is more complicated and expensive, substituting active system with the passive for high power battery pack applications (e.g., E-truck) reduces thermal issues while providing higher energy efficiency. Future research in cell equalization is considered using wide band gap devices and smart intelligent techniques to improve existing solutions.

According to the international energy agency (IEA) report, the expected growth of renewable energy capacity is around $218 \mathrm{GW}$ in 2021 , nearly $10 \%$ higher than 2020 (200 GW). Renewable capacity additions are led by solar PV (around 54\%) and wind (around 31\%) respectively. The strong growth is mainly because of projects delayed in the last year due to COVID-19 pandemic (www.iea.org).

\section{Acknowledgments}

This work is supported by Robert Bosch Engineering and Business Solutions Limited, Bengaluru, India.

\section{References}

Abronzini, U., Di Monaco, M., Porpora, F., Tomasso, G., D'Arpino M., \& Attaianese, C. (2019). Thermal Management Optimization of a Passive BMS for Automotive Applications. AEIT International Conference of Electrical and Electronic Technologies for Automotive,1-6; doi: 10.23919/eeta.2019.8804559

Aizpuru, I., Iraola, U., Canales, J.M., Goikoetxea, A., \& Garayalde, E. (2017). Comparative Study and Evaluation of Passive Balancing Against Single Switch Active Balancing Systems for Energy Storage Systems. Int. J. Sci. Res, 7(3), 19 .
Amin, Ismail, K., Nugroho, A., \& Kaleg, S. (2017). Passive balancing battery management system using MOSFET internal resistance as balancing resistor. 2017 International Conference on Sustainable Energy Engineering and Application, 151-155; doi:10.1109/icseea.2017. 8267701

Andrea, D. (2010). Battery Management Systems for Large Lithium-Ion Battery Packs. Artech House.

Campbell, I.D., Gopalakrishnan, K., Marinescu, M., Torchio, M., Offer, G.J., \& Raimondo, D. (2019). Optimising lithium-ion cell design for plug-in hybrid and battery electric vehicles. $J$. Energy Storage, 22, 228-238; doi: 10.1016/j.est.2019.01.006

Carter, J., Fan, Z., \& Cao, J. (2020). Cell equalisation circuits: A review. J. Power Sources, 448; doi:10.1016/j.jpowsour.2019.227489

Caspar, M., Eiler, T., \& Hohmann, S. (2018). Systematic Comparison of Active Balancing: A Model-Based Quantitative Analysis. IEEE Trans. Veh. Technol, 67(2), 920-934; doi: 10.1109/tvt.2016.2633499.

Cassani, P., \& Williamson, S.S. (2009). Feasibility Analysis of a Novel Cell Equalizer Topology for Plug-In Hybrid Electric Vehicle Energy-Storage Systems. IEEE Trans. Veh. Technol, 58,3938 - 3946 . doi: 10.1109/TVT.2009.2031553.

Chen, Z., Lu, J., Liu, B., Zhou, N., \& Li, S. (2020). Optimal energy management of plug-in hybrid electric vehicles concerning the entire lifespan of lithium-ion batteries. Energies, 13(10), 2543; doi: 10.3390/en13102543

Chol-Ho, K., Moon-Young, K., \& Gun-Woo, M. (2013). A modularized charge equalizer using a battery monitoring IC for series-connected Li-Ion battery strings in electric vehicles. IEEE Trans. Power Electron, 28(8), 37793787; doi: 10.1109/tpel.2012.2227810

Collin, R., Miao, Y., Yokochi, A., Enjeti, P., \& Von Jouanne, A. (2019). Advanced Electric Vehicle Fast-Charging Technologies. Energies, $\quad 12(10), \quad 1839$; doi: 10.3390/en12101839

Daowd, M., Omar, N., Van den Bossche, P., \& Van Mierlo, J. (2011). A Review of Passive and Active Battery Balancing based on MATLAB/Simulink. Int. Rev. Electr Eng, 6(7). 29742989.

Dong, B., Li, Y., \&Han.Y. (2015). Parallel Architecture for Battery Charge Equalization. IEEE Trans. Power Electron, 30(9), 4906-4913; doi: 10.1109/tpel.2014.2364838

Deng, Y., Li, J., Li, T., Zhang, J., Yang, F., \& Yuan, C. (2017). Life cycle assessment of high-capacity molybdenum disulfide lithium-ion battery for electric vehicles. Energy, 123, 7788. doi: 10.1016/j.energy.2017.01.096

Deng, Y., Ma, L., Li, T., Li, J., \& Yuan, C. (2019). Life Cycle Assessment of Silicon-Nanotube-Based Lithium-Ion Battery for Electric Vehicles. ACS Sustainable Chemistry and Engineering, 7 (1), 599-610; doi: $10.1021 /$ acssuschemeng. 8 b04136

Gallardo-Lozano, J., Romero-Cadaval, E., Milanes-Montero, M., \& Guerrero-Martinez, M. (2014). Battery equalization active methods. J. Power Sources. 246. 934-949. doi: 10.1016/j.jpowsour.2013.08.026.

Hemavathi, S.(2020). Overview of cell balancing methods for Liion battery technology. Energy storage. e203. doi: 10.1002/est2.203

Hoque, M.M., Hannan, M.A., \& Mohamed, A. (2015). Voltage equalization for series connected lithium-ion battery cells. IEEE $3^{\text {rd }}$ International conference on smart instrumentation, measurement \& Applications. 1-6; doi:10.1109/icsima.2015.7559015

Hua, Y., Zhou, S., Cui, H., Liu, X., Zhang, C., Xu, X., Ling, H., \& Yang, S. (2020). A comprehensive review on inconsistency and equalization technology of lithium-ion battery for electric vehicles. Int. J. Energy Res, 44(14), 11059-11087; doi: 10.1002/er.5683

Jung, C. (2017). Power Up with 800-V Systems: The benefits of upgrading voltage power for battery-electric passenger 
vehicles. IEEE Electrification Magazine, 5(1), 53-58; doi: $10.1109 /$ mele.2016.2644560

Kim, M., Kim, J., \& G. Moon. (2014). Center-Cell Concentration Structure of a Cell-to-Cell Balancing Circuit with a Reduced Number of Switches. IEEE Trans. Power Electron, 29(10),5285-5297; doi: 10.1109/tpel.2013.2292078

Koseoglou, M., Tsioumas, E., Jabbour. N., \&Mademlis, C. (2020). Highly Effective Cell Equalization in a Lithium-Ion Battery Management System. IEEE Trans. Power Electron, 35(2), 2088-2099; doi: 10.1109/tpel.2019.2920728

Lee, Y., Jeon, S., \& Bae, S. (2016). Comparison on Cell Balancing Methods for Energy Storage Applications. Indian J. Sci. Technol. 9. doi:10.17485/ijst/2016/v9i17/92316.

Lei, B., Zhao, W., Ziebert, C., Uhlmann, N., Rohde, M.,\& Seifert, H. (2017). Experimental Analysis of Thermal Runaway in 18650 Cylindrical Li-Ion Cells Using an Accelerating Rate Calorimeter. Batteries, 3(4), 14; doi: 10.3390/batteries3020014

Lipu, M.S.H., Hannan, M.A., Hussain, A., Hoque, M.M., Ker, P.J., Saad, M.H.M., \& Ayob, A. (2018). A review of state of health and remaining useful life estimation methods for lithium-ion battery in electric vehicles: Challenges and recommendations. J. Clean. Prod, 205, 115-133; doi: 10.1016/j.jclepro.2018.09.065

Li, W., Chen, S., Peng, X., Xiao, M., Gao, L., Garg, A.,\& Bao, N. (2019). A Comprehensive Approach for the Clustering of Similar-Performance Cells for the Design of a Lithium-Ion Battery Module for Electric Vehicles. Engineering, 5(4), 795802; doi: 10.1016/i.eng.2019.07.005

Ma, Y., Duan, P., Sun, Y., \& Chen, H. (2018). Equalization of Lithium-Ion Battery Pack Based on Fuzzy Logic Control in Electric Vehicle. IEEE Trans. Ind. Electron, 65 (8), 67626771; doi: 10.1109/tie.2018.2795578

Ma, L., Nie, M., Xia, J., \& Dahn, J.R. (2016). A systematic study on the reactivity of different grades of charged $\mathrm{Li}$ [NixMnyCoz]O2 with electrolyte at elevated temperatures using accelerating rate calorimetry. J. Power Sources, 327,145-150; doi: 10.1016/j.jpowsour.2016.07.039

Moghaddam, A.F., \& Van Den Bossche, A. (2018). An Active Cell Equalization Technique for Lithium Ion Batteries Based on Inductor Balancing. 9th International Conference on Mechanical and Aerospace Engineering (ICMAE), 274-278; doi: 10.1109/icmae.2018.8467685

Moghaddam, A.F., \& Van Den Bossche, A. (2019). An efficient equalizing method for lithium-ion batteries based on coupled inductor balancing. Electronics, 8(2), 136; doi: $10.3390 /$ electronics 8020136

Narayanaswamy, S., Steinhorst, S., Lukasiewycz, M., Kauer, M., \& Chakraborty, S. (2014). Optimal dimensioning of active cell balancing architectures. 2014 Design, Automation \& Test in Europe Conference \& Exhibition (DATE), 1-6; doi: $10.7873 /$ date. 2014.153

Omariba, Z., Zhang, L., \& Sun, D. (2018). Review on Health Management System for Lithium-Ion Batteries of Electric
Vehicles.

Electronics,

$7(5)$

72 ; doi: 10.3390/electronics7050072

Omariba, Z., Zhang, L., \& Sun, D. (2019). Review of Battery Cell Balancing Methodologies for Optimizing Battery Pack Performance in Electric Vehicles. IEEE Access, 1-1; doi: $10.1109 /$ access. 2019.2940090

Phung, T.H., Collet, A., J. Crebier. (2014). An Optimized Topology for Next-to-Next Balancing of Series-Connected Lithium-ion Cells. IEEE Trans. Power Electron, 29(9), 4603-4613; doi: 10.1109/tpel.2013.2284797

Stuart, T., \& Zhu, W. (2009). Fast equalization for large lithiumion batteries. Aerospace and Electronic Systems Magazine, IEEE. 24, 27 - 31; doi: 10.1109/maes.2009.5208557

Thiruvonasundari, D., \& Deepa, K. (2020). Active cell balancing for electric vehicle battery management system. Int. J. Power Electron. Drive Syst.11(2),

571-579; doi: 10.11591/ijpeds.v11.i2.pp571-579

Thiruvonasundari, D., \& Deepa, K. (2020). Electric Vehicle Battery Modelling Methods Based on State of Charge-Review. J. Green Eng., 10(1), 24-61.

Tomaszewska, A., Feng, X., Chu, Z., \& O'Kane, S. (2019). Lithium-Ion Battery Fast Charging: A Review. eTransportation, 1; doi: 10.1016/j.etran.2019.100011

Vardhan, R., Thavassy, S., Reginald, R., Sivakumar, P., \& Sundaresh, S. (2017). Modeling of single inductor based battery balancing circuit for hybrid electric vehicles. IECON -43rd Annual Conference of the IEEE Industrial Electronics Society, 2293-2298; doi: 10.1109/iecon.2017.8216386

Wager, G., Whale, J., \& Braunl, T. (2016). Battery cell balance of electric vehicles under fast-DC charging. Int. $J$. Electr. Hybrid Veh, 8, 351; doi:10.1504/ijehv.2016.080732.

Wang, S., Kang, L., Guo, X., Wang, Z., \&M. Liu. (2017). A Novel Layered Bidirectional Equalizer Based on a Buck-Boost Converter for Series-Connected Battery Strings. Energies, 10(7),1011; doi: 10.3390/en10071011

Xie, J. P., Wei, X. Z., \& Dai, H. F. (2011). Inductor-Based Active Balancing of Li-Ion Battery. Appl. Mech. Mater, 80-81, 255260. doi:10.4028/www.scientific.net/amm.80-81.255

Xu, J., Mei, X., \& Wang, J. (2019). A High Power Low-Cost Balancing System for Battery Strings, Energy Procedia, 158, 2948-2953, doi:10.1016/j.egypro.2019.01.956.

Zheng, Y., Ouyang, M., Han, X., Lu, L., \& Li, J. (2018). Investigating the error sources of the online state of charge estimation methods for lithium-ion batteries in electric vehicles J. Power Sources, 377, 161-188; doi: 10.1016/j.jpowsour.2017.11.094

Zhou, Z., Duan, B., Shang, Y., \& Zhang, C. (2016). An any-cell(s)to-any-cell(s) equalizer based on bidirectional inductor converters for series connected battery string. 2016 IEEE 11th Conference on Industrial Electronics and Applications (ICIEA), 2511-2515; doi: 10.1109/iciea.2016.7604015 